\title{
Tensile bond strength of self-etching versus total-etching adhesive systems under different dentinal substrate conditions
}

\author{
Resistência de união à tração de sistemas \\ adesivos autocondicionantes versus de \\ condicionamento total, em diferentes condições \\ de substrato dentinário
}

\begin{abstract}
Alexandre Henrique Susin ${ }^{(a)}$ Walison Arthuso Vasconcellos ${ }^{(b)}$ José Roberto Cury Saad(c) Osmir Batista de Oliveira Junior(c)
\end{abstract}

(a) $\mathrm{PhD}$, Department of Restorative Dentistry, Santa Maria University.

(b) PhD, Department of Restorative Dentistry, Montes Claros University.

(c) PhDs, Department of Restorative Dentistry, School of Dentistry of Araraquara, São Paulo State University.

\section{Corresponding author:}

Walison Arthuso Vasconcellos Rua Nova Ponte, 148

Salgado Filho - Belo Horizonte MG - Brazil - CEP: 30550-720

E-mail: vasconcelloswa@hotmail.com

Received for publication on Aug 17, 2005 Sent for alterations on Oct 05, 2005

Accepted for publication on Oct 02, 2006

\begin{abstract}
The use of acid etchants to produce surface demineralization and collagen network exposure, allowing adhesive monomers interdiffusion and consequently the formation of a hybrid layer, has been considered the most efficient mechanism of dentin bonding. The aim of this study was to compare the tensile bond strength to dentin of three adhesive systems, two self-etching ones (Clearfil SE Bond - CSEB and One Up Bond F OUBF) and one total-etching one (Single Bond - SB), under three dentinal substrate conditions (wet, dry and re-wet). Ninety human, freshly extracted third molars were sectioned at the occlusal surface to remove enamel and to form a flat dentin wall. The specimens were restored with composite resin (Filtek Z250) and submitted to tensile bond strength testing (TBS) in an MTS 810. The data were submitted to two-way ANOVA and Tukey's test $(\mathrm{p}=0.05)$. Wet dentin presented the highest TBS values for SB and CSEB. Dry dentin and re-wet produced significantly lower TBS values when using SB. OUBF was not affected by the different conditions of the dentin substrate, producing similar TBS values regardless of the surface pretreatments.
\end{abstract}

Descriptors: Dentin permeability; Dentin-bonding agents; Tensile strength.

Resumo: O uso de condicionadores ácidos para desmineralizar a superfície dental e expor a rede de fibras colágenas para interdifusão dos monômeros adesivos e conseqüente formação da camada híbrida tem sido considerado o mais eficiente mecanismo de adesão dos agentes de união. O objetivo deste estudo foi comparar a resistência de união à dentina de três sistemas adesivos, dois autocondicionantes (Clearfil SE Bond - CSEB e One Up Bond F - OUBF) e um de condicionamento total (Single Bond - SB), sob três diferentes condições de substrato dentinário (úmido, seco e reidratado). Noventa terceiros molares humanos recém-extraídos foram cortados na superfície oclusal, para se remover o esmalte e formar uma parede plana de dentina. Os espécimes foram restaurados com resina composta (Filtek Z250) e submetidos ao teste de resistência de união à tração (TBS) em uma MTS 810. As médias foram submetidas à ANOVA a dois critérios e ao teste de Tukey $(\mathrm{p}=0,05)$. A dentina úmida apresentou os maiores valores de TBS para os sistemas adesivos SB e CSEB. A dentina seca e a reidratada apresentaram TBS significativamente menor quando foi empregado SB. OUBF não apresentou resultados influenciados pela condição do substrato dentinário, tendo produzido TBS similares para os diferentes tratamentos de superfície.

Descritores: Permeabilidade da dentina; Adesivos dentinários; Resistência à tração. 


\section{Introduction}

Dental adhesive systems are agents used to promote adhesion between composite resin and dental structure, and they should present similar performance on enamel and dentin. However, the success of bonding to these dental hard tissues, without a previous acid-etching step, represents a major challenge for adhesive dentistry. ${ }^{2}$

Dentin etching, prior to the application of primer and adhesive, is necessary as part of restorative adhesive procedures for removing the smear layer and exposing the collagen fibrils of the dentinal matrix in order to promote infiltration of resinous monomers. As a consequence, it is possible to obtain good marginal adaptation of the restorative material, thus reducing microleakage, pulpal irritation and recurrent caries. ${ }^{12,14,16,17}$

Resin bonding is not as easy for dentin as it is for enamel, since dentin has more organic contents, the presence of fluid inside tubules, smear layer and inherent wetness on the surface. ${ }^{4,5,7,14,19}$ During the bonding process, there is diffusion of hydrophilic monomers into the demineralized dentin collagen network. However, the discrepancy in the thickness of demineralization and hydrophilic monomer infiltration is still an unsolved problem. ${ }^{1,2,13}$ Thus, a new concept, which presents acid and primer in the same component, ${ }^{13}$ has been considered with the application of self-etching agents, eliminating the previous conditioning, rinsing and drying steps that may be critical for the adhesion protocol. Theoretically, there is no discrepancy between the depth of demineralization and the depth of resin infiltration, since both processes occur simultaneously, ${ }^{15}$ but in a recent study it was demonstrated that beneath the hybrid layer a partially demineralized and uninfiltrated dentin zone can be observed. ${ }^{3}$ The total-etch and self-etch adhesive systems are contemporary and they are dividing the preference of clinicians, mainly when technical simplification versus effectiveness of adhesion to different dentinal substrates is considered. 2,10,15

The aim of this study was to compare the tensile bond strength of three adhesive systems to dentin, two self-etching (Clearfil SE Bond - CSEB and One Up Bond F - OUBF), and one total-etching (Single Bond - SB), under three different dentinal substrate conditions, dry, wet and re-wetted.

\section{Material and Methods}

Ninety human, recently extracted third molars were stored at $5^{\circ} \mathrm{C}$ in a $0.5 \%$ chloramine aqueous solution for a maximum period of time of 45 days, until their use in this study (Research Ethics Committee, School of Dentistry of Araraquara, N. 194/2001). The enamel was removed by cutting off the crown transversally at the middle, exactly at the top of the pulp chamber, using a low speed diamond saw (Isomet 1000, Buehler Lake Bluff, IL, USA). The deep dentin was chosen to favour the diffusion of dentin adhesive into the demineralized dentin, thus providing the best conditions for the resin monomers to infiltrate into the dentin since the number of tubules in coronal dentine increases significantly from the middle to the deep layer, nearest to the pulp. ${ }^{24} \mathrm{~A}$ standard smear layer was produced by wet-sanding the dentin surface with 600 -grit silicon carbide sandpaper for 40 seconds.

The ninety specimens were embedded in epoxy resin and randomly divided into nine groups of ten teeth each. The regions of interest for adhesion were demarked in each sample using a glue paper mask with a $4.0 \mathrm{~mm}$ diameter hole in the center isolating the peripheral region and, afterwards, each adhesive system was applied. Three adhesive systems, two self-etching (Clearfil SE Bond, Kuraray Co. Osaka, Japan and One Up Bond F, Tokuyama, Tokyo, Japan) and one total-etching (Single Bond, 3M ESPE, St. Paul, MN, USA), were used in this study and they were applied after obtaining three different dentinal substrate conditions, wet, dry and re-wet, following the techniques shown in Table 1 . The authors opted to increase the etching time to 20 seconds for the dry and re-wet dentin, with the objective of creating a more severe condition.

The specimens were restored using Filtek Z250 composite resin (3M ESPE, St. Paul, MN, USA) in four diagonal increments inside a conical-cylinder metallic matrix adequately adapted on the top of the bonded area. The conical-cylinder metallic matrix was installed exactly over the hole mask, resulting in a circular bonding area with a diameter of $4.0 \mathrm{~mm}$. Each new increment was photocured using a KM200R unit (DMC Equip. Odontol., São Carlos, SP, Brazil) during 40 seconds. 
Table 1 - Dentin treatments - substrate conditions and bonding technique.

\begin{tabular}{|c|c|c|c|}
\hline & $\begin{array}{l}\text { Wet dentin (Substrate 1) } \\
n=10\end{array}$ & $\begin{array}{l}\text { Acid-etched/dry dentin (Substrate 2) } \\
\mathrm{n}=10\end{array}$ & $\begin{array}{l}\text { Acid-etched/re-wet dentin (Substrate 3) } \\
n=10\end{array}$ \\
\hline $\begin{array}{l}\text { Clearfil SE Bond } \\
\text { (CSEB - M1) }\end{array}$ & $\begin{array}{l}\text { - Primer: apply for } 20 \mathrm{~s} \text { and } \\
\text { air-dry. } \\
\text { - Adhesive: apply, gently air-thin. } \\
\text { - Light-cure for } 10 \mathrm{~s} \text {. }\end{array}$ & $\begin{array}{l}\text { - } 35 \% \text { phosphoric acid for } 20 \mathrm{~s} \text {. } \\
\text { - Compressed air application for } \\
20 \mathrm{~s} \text {. } \\
\text { - Primer: apply for } 20 \mathrm{~s} \text { and air-dry. } \\
\text { - Adhesive: apply, gently air-thin. } \\
\text { - Light-cure for } 10 \mathrm{~s} \text {. }\end{array}$ & $\begin{array}{l}\text { - } 35 \% \text { phosphoric acid for } 20 \mathrm{~s} \text {. } \\
\text { - } 10.0 \text { m distance-compressed air } \\
\text { application for } 20 \mathrm{~s} \text {. } \\
\text { - } 2 \% \text { chlorhexidine digluconate aqueous } \\
\text { solution for } 60 \mathrm{~s} \text {. } \\
\text { - Primer: apply for } 20 \mathrm{~s} \text { and air-dry. } \\
\text { - Adhesive: apply, gently air-thin. } \\
\text { - Light cure for } 10 \mathrm{~s} \text {. }\end{array}$ \\
\hline $\begin{array}{l}\text { One Up Bond F } \\
\text { (OUBF - M2) }\end{array}$ & $\begin{array}{l}\text { - Bonding A and B mixed for } 20 \mathrm{~s} \text {. } \\
\text { - Light-cure for } 10 \mathrm{~s} \text {. }\end{array}$ & $\begin{array}{l}\text { - } 35 \% \text { phosphoric acid for } 20 \mathrm{~s} \text {. } \\
\text { - Compressed air application for } \\
20 \mathrm{~s} \text {. } \\
\text { - Bonding A and B mixed for } 20 \mathrm{~s} \text {. } \\
\text { - Light-cure for } 10 \mathrm{~s} \text {. }\end{array}$ & $\begin{array}{l}\text { - } 35 \% \text { phosphoric acid for } 20 \mathrm{~s} \text {. } \\
\text { - } 10.0 \text { mm distance-compressed air } \\
\text { application for } 20 \mathrm{~s} \text {. } \\
\text { - } 2 \% \text { chlorhexidine digluconate aqueous } \\
\text { solution for } 60 \mathrm{~s} \text {. } \\
\text { - Bonding } \mathrm{A} \text { and } \mathrm{B} \text { mixed for } 20 \mathrm{~s} \text {. } \\
\text { - Light-cure for } 10 \mathrm{~s} \text {. }\end{array}$ \\
\hline $\begin{array}{l}\text { Single Bond } \\
\text { (SB-M3) }\end{array}$ & $\begin{array}{l}\text { - } 35 \% \text { phosphoric acid for } 20 \mathrm{~s} \text {. } \\
\text { - Rinse off with air-water spray } \\
\text { - Apply } 2 \text { layers, gently air-thin } \\
\text { for } 5 \mathrm{~s} \text {. } \\
\text { - Light-cure for } 10 \mathrm{~s} \text {. }\end{array}$ & $\begin{array}{l}\text { - } 35 \% \text { phosphoric acid for } 20 \mathrm{~s} \text {. } \\
\text { - Compressed air application for } \\
20 \mathrm{~s} \text {. } \\
\text { - Apply } 2 \text { layers, gently air-thin for } \\
5 \mathrm{~s} \text {. } \\
\text { - Light-cure for } 10 \mathrm{~s} \text {. }\end{array}$ & $\begin{array}{l}\text { - } 35 \% \text { phosphoric acid for } 20 \mathrm{~s} \text {. } \\
\text { - } 10.0 \text { mm-distance compressed air } \\
\text { application for } 20 \mathrm{~s} \text {. } \\
\text { - } 2 \% \text { chlorhexidine digluconate aqueous } \\
\text { solution for } 60 \mathrm{~s} \text {. } \\
\text { - Apply } 2 \text { layers, } 5 \mathrm{~s} \text { gently air-thin. } \\
\text { - Light-cure for } 10 \mathrm{~s} \text {. }\end{array}$ \\
\hline
\end{tabular}

After being stored for 24 hours in distilled water at room temperature, the specimens were thermocycled for 550 cycles at temperatures from $5^{\circ}$ to $60^{\circ} \mathrm{C}$ with a dwell time of 15 seconds in each bath and a transfer time of 5 seconds.

The tensile bond strength was measured in an MTS-810 machine (Material Test Systems, Edemprairie, MN, USA) at $2 \mathrm{~mm} / \mathrm{min}$. The data were submitted to statistical analysis using two-way ANOVA: adhesive system and dentinal substrate. When significant differences were found, Tukey's test was applied at a $5 \%$ level of significance.

\section{Results}

The obtained tensile bond strength values are shown in Graph 1 and Table 2. Tensile bond strength ranged from $6.6 \mathrm{MPa}$ for the total-etching adhesive system SB, bonded to dry dentin, to 23.1 MPa for the self-etching adhesive CSEB, bonded to wet dentin. When the self-etching adhesive systems were compared under wet dentin, CSEB presented better results than OUBF (23.1 and 15.7 MPa, respectively).

Comparing the total-etching adhesive system SB to the two self-etching adhesive systems, the low-

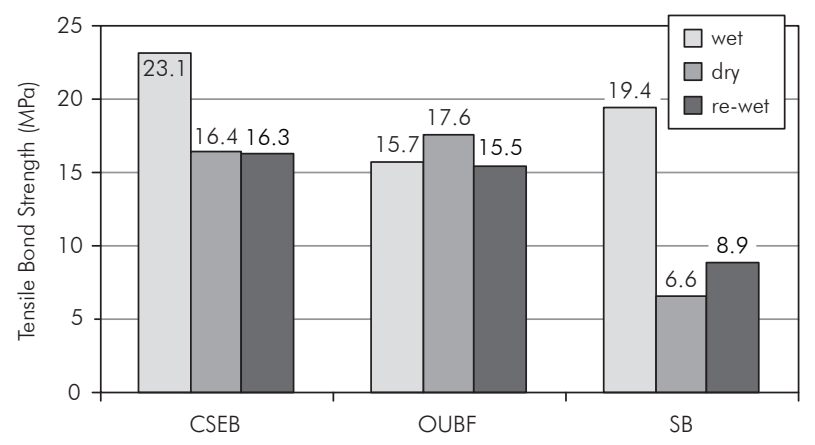

Graph 1 - Tensile Bond Strength (means in MPa). Adhesive systems versus dentinal substrate conditions.

est results were found for $\mathrm{SB}(6.6 \mathrm{MPa}$ - dry to 8.9 $\mathrm{MPa}$ - re-wet), which were significantly different from the results found for the self-etching adhesives CSEB and OUBF on the same dentinal substrate, which ranged from 15.5 MPa to 17.6 MPa.

\section{Discussion}

Adhesion of resins to dentin has been the main subject of numerous studies since adhesive systems were introduced in restorative dentistry. ${ }^{1,2,4,6,16}$ The bond strength must be an opposite resistance to 
Table 2 - Multiple comparisons by Tukey's test of the TBS means.

\begin{tabular}{|c|c|c|c|c|c|c|c|c|c|}
\hline Group & $\begin{array}{l}\text { mean } \\
(\mathrm{MPa})\end{array}$ & (1) & (2) & (3) & (4) & (5) & (6) & (7) & (8) \\
\hline $\begin{array}{l}\text { 1. CSEB/wet } \\
\text { dentin (S1) }\end{array}$ & 23.1 & & & & & & & & \\
\hline $\begin{array}{l}\text { 2. CSEB/Dry } \\
\text { dentin (S2) }\end{array}$ & 16.4 & * & & & & & & & \\
\hline $\begin{array}{l}\text { 3. CSEB/Re-wet } \\
\text { dentin (S3) }\end{array}$ & 16.3 & * & ns & & & & & & \\
\hline $\begin{array}{l}\text { 4. OUBF/wet } \\
\text { dentin (S1) }\end{array}$ & 15.7 & * & ns & ns & & & & & \\
\hline $\begin{array}{l}\text { 5. OUBF/Dry } \\
\text { dentin (S2) }\end{array}$ & 17.6 & * & $\mathrm{ns}$ & ns & ns & & & & \\
\hline $\begin{array}{l}\text { 6. OUBF/ } \\
\text { Re-wet dentin } \\
\text { (S3) }\end{array}$ & 15.5 & * & ns & ns & ns & ns & & & \\
\hline $\begin{array}{l}\text { 7. SB/wet } \\
\text { dentin (S1) }\end{array}$ & 19.4 & ns & $\mathrm{ns}$ & ns & ns & ns & ns & & \\
\hline $\begin{array}{l}\text { 8. SB/Dry } \\
\text { dentin (S2) }\end{array}$ & 6.6 & * & $*$ & * & * & $*$ & $*$ & $*$ & \\
\hline $\begin{array}{l}\text { 9. SB/Re-wet } \\
\text { dentin (S3) }\end{array}$ & 8.9 & * & * & $*$ & * & $*$ & $*$ & $*$ & ns \\
\hline
\end{tabular}

$*$ = significant level of $5 \%, \mathrm{~ns}=$ not significant.

the polymerization contraction stresses, offer retention and provide marginal integrity for the restoration. ${ }^{13,19,22}$

Dentin bonding still faces questions related to the appropriate humidity level for better hibridization, protection of the pulp and to seal adequately the cavity margins. ${ }^{6,10,17,20,26}$

The depth of demineralization promoted by the phosphoric acid determines the thickness of the hybrid layer, as the application of the phosphoric acid before the primer or primer/adhesive acts by removing the smear layer, demineralizing the dentin structure and consequently exposing colagen fibrils to allow the formation of the hybrid layer. ${ }^{6,17,21}$ The maintenance of the collagen fibrils network in wet acid-etched dentin makes the infiltration of hydrophilic monomers easier, ${ }^{19,20,25}$ while the drying of the etched dentin with air makes monomer infiltration more difficult due to a severe reduction of interfibrilar spaces. ${ }^{12}$

The morphology of the adhesive interface has been studied to identify hybridization patterns provided by several adhesive systems, under many different dentinal substrate conditions. ${ }^{7,10,16,27}$ The collagen fibril mesh collapse, caused by dentin dehydration, ${ }^{12,17}$ limits the possibility of the micromechanical retention of the adhesive system in primed dentin. However, if the meshwork is re-expanded, there is an improvement of the microtensile bond strength. ${ }^{11}$ This work incorporated a third condition of dentinal substrate, re-wet, where dehydrated dentin received an application of $2 \%$ chlorhexidine digluconate solution for 60 seconds. Although studies by Filler et al. ${ }^{8}$ (1994) demonstrated that a chlorhexidine digluconate solution did not interfere in the tensile bond strength, the statements of Gwinnett ${ }^{11}$ (1994) agree with the findings of this study, since the results obtained for re-wet dentin were better than those obtained for dry dentin.

Tay et al. ${ }^{26}$ (1996) performed studies where dentin, after being dried with compressed air for 3 seconds, went through a remoistening process with distilled water. The authors noticed that the samples presented difficulties in the infiltration of the adhesive. In the present study, etched dentin was air-dried with compressed air for 20 seconds, which caused severe dehydration of the etched matrix and decreased the means of the bond strengths. Gwinnett ${ }^{11}$ (1994) stated that dehydrated dentin could provide a bond strength close to that obtained in wet dentin, if it was remoistened and the collagen fibrils re-expanded.

While the total-etching adhesive systems need a separate and previous etching step, self-etch adhesive systems, such as Clearfil SE Bond, etch and prime in the same step; One Up Bond F etches, primes and bonds simultaneously, so it is called an all-in-one adhesive system. These products produce smear layer dissolution ${ }^{2,21,23}$ and dentin self-controlling demineralization by $\mathrm{pH}$ modifications during their application. Since the primer or primer/adhesive itself is the substance performing demineralization, it is understood that the entire demineralized dentin thickness will be filled with adhesive monomers, which cannot be surely confirmed when acid application, cleaning and surface drying are performed in separate steps previously to the application of hydrophilic monomers, as it happens with the total-etch adhesive systems. , $18,19,21,23$ 
The tensile bond strengths provided by CSEB and OUBF to wet dentin presented statistically significant differences $(23.1 \mathrm{MPa}$ and $15.7 \mathrm{MPa}$, respectively). When CSEB was used on acid-etched dried dentin, the tensile bond strength was $16.4 \mathrm{MPa}$, while OUBF presented a mean of $17.6 \mathrm{MPa}$. When these products were applied to re-wetted dentin with $2 \%$ chlorhexidine in water, the tensile bond strength values of CSEB and OUBF were $16.3 \mathrm{MPa}$ and $15.5 \mathrm{MPa}$, respectively.

When the results observed in all groups were compared, the better performance of CSEB on wet dentin could be emphasized. Its efficacy on wet dentin proved to be the best in this criterion, among all the materials tested, thus agreeing with the results obtained by Spohr et al. ${ }^{25}$ (2001). The adhesive system Clearfil SE Bond is characterized as a self-etch primer with $\mathrm{pH}$ about 1.9. After its application, the acid is totally neutralized by phosphate ions during demineralization. On the other hand, OUBF, which

\section{References}

1. Armstrong SR, Boyer DB, Keller JC. Microtensile bond strength testing and failure analysis of two dentin adhesives. Dent Mater. 1998;14(1):44-50.

2. Bouillaguet S, Gysi P, Watana JC, Ciucchi B, Cattani M, Godin $\mathrm{CH}$. Bond strength of composite to dentin using conventional, one-step and self-etching adhesive systems. J Dent. 2001;29(1):55-61.

3. Carvalho RM, Chersoni S, Frankenberger R, Pashley DH, Prati C, Tay FR. A challenge to the conventional wisdom that the simultaneous etching and resin infiltration always occurs in self-etch adhesives. Biomaterials. 2005;26(9):1035-42.

4. Carvalho RM, Mendonça JS, Santiago SL, Silveira RP, Garcia FC, Tay FR, et al. Effects of HEMA/solvent combinations on bond strength to dentin. J Dent Res. 2003;82(8):597-601.

5. Chaves P, Giannini M, Ambrosano GM. Influence of smear layer pretreatments on bond strength to dentin. J Adhes Dent. 2002;4(3):191-6.

6. De Goes MF, Pachane GCF, Garcia-Godoy F. Resin bond strength with different methods to remove excess water from the dentin. Am J Dent. 1997;10(6):298-301.

7. Elhabashy A, Swift Jr EJ. Bonding to etched, physiologically hydrated dentin. Am J Dent. 1994;7(1):50-2.

8. Filler SJ, Lazerchik DA, Givan D, Retief DH, Heaven RJ. Shear bond strengths of composite to chlorhexidine-treated enamel. Am J Dent. 1994;7(2):85-8. has a $\mathrm{pH}$ around 1.0, provided the lowest tensile bond strength, on wet dentin, among the three materials tested. In spite of the importance of $\mathrm{pH}$ values to understand the efficacy of self-etching adhesive systems, it is not possible to consider that the $\mathrm{pH}$ alone is responsible for the performance of the adhesive systems since their composition is an important factor of influence at the interfacial aspect. ${ }^{9}$

\section{Conclusion}

The results of the present study demonstrated that the performance of CSEB and SB were influenced by the dentinal substrate condition in the tensile bond strength test, while the OUBF adhesive system did not suffer any interference of the dentinal substrate condition. The more evident harm caused by drying and re-wetting dentin occurred when the total-etching adhesive system was utilized. This demonstrated that its performance can be harmed by the dentin drying step following acid conditioning.

9. Grégoire G, Milas A. Microscopic evaluation of dentin interface obtained with 10 contemporary self-etching systems: correlation with their pH. Oper Dent. 2005;30(4):481-91.

10. Gwinnett AJ. Altered tissue contribution to interfacial bond strength with acid conditioned dentin. Am J Dent. 1994;7(5):243-6.

11. Gwinnett AJ. Dentin bond strength after air drying and rewetting. Am J Dent. 1994;7(3):144-8.

12. Gwinnett AJ, Tay F, Pang KM, Wei SHY. Quantitative contribution of the collagen network in dentin hybridization. Am J Dent. 1996;9(4):140-4.

13. Inoue S, Vargas MA, Abe Y, Yoshida Y, Lambrechts P, Vanherle G, et al. Microtensile bond strength of eleven contemporary adhesives to dentin. J Adhes Dent. 2001;3(3):237-45.

14. Kato G, Nakabayashi N. The durability of adhesion to phosphoric acid etched wet dentin substrates. Dent Mater. 1998;14(5):347-52.

15. Koibuchi H, Yasuda N, Nakabayashi N. Bonding to dentin with a self-etching primer: the effect of smear layers. Dent Mater. 2001;17(2):122-6.

16. Leite FRM, Capote TSO, Zuanon ACC. Application of the total etching technique or self-etching primers on primary teeth after air abrasion. Braz Oral Res. 2005;19(3):198-202

17. Nakabayashi N, Sami Y. Bonding to intact dentin. J Dent Res. 1996;75(9):1706-15. 
18. Pashley DH, Zhang Y, Agee KA, Rouse CJ, Carvalho RM, Russel CM. Permeability of demineralized dentin to HEMA. Dent Mater. 2000;16(1):7-14.

19. Perdigão J, Lambrechts P, van Meerbeek B. The interaction of adhesive systems with human dentin. Am J Dent. 1996;9(4):167-73.

20. Perdigão J, Swift EJ, Heymann HO, Malek MA. Effect of a re-wetting agent on the performance of acetone-based dentin adhesives. Am J Dent. 1998;11(5):207-13.

21. Prati C, Chersoni S, Mongiorgi R, Pashley DH. Resin-infiltrated dentin layer formation of new bonding systems. Oper Dent. 1998;23(4):185-94.

22. Retief DH, Mandras RS, Russel CM. Shear bond strength required to prevent microleakage at the dentin/restoration interface. Am J Dent. 1994;7(1):44-6.

23. Rosales-Leal JI, Osorio R, Holgado-Terriza JA, CabrerizoVílchez MA, Toledano M. Dentin wetting by four adhesive systems. Dent Mater. 2001;17(6):526-32.
24. Schilke R, Lisson JA, Bauss O, Geurtsen W. Comparison of the number and diameter of dentinal tubules in human and bovine dentine by scanning electron microscopic investigation. Arch Oral Biol. 2000;45(5):355-61.

25. Spohr AM, Conceição EN, Pacheco JFM. Tensile bond strength of four adhesive systems to dentin. Am J Dent. 2001;14(4):247-51.

26. Tay FR, Gwinnett AJ, Wei SH. The overwet phenomenon: a scanning electron microscopic study of surface moisture in the acid-conditioned, resin-dentin interface. Am J Dent. 1996;9(3):109-14.

27. Tay FR, Gwinnett AJ, Wei SH. Ultrastructure of the resin-dentin interface following reversible and irreversible rewetting. Am J Dent. 1997;10(2):77-82. 